\title{
Effects of Using Computer-Based Activities in Teaching English Speaking at a High School in Ho Chi Minh City, Vietnam
}

\author{
Nguyen Thi My Nhu ${ }^{1,2^{*}}$
}

${ }^{1}$ Binh Hung Hoa High School, Ho Chi Minh City, Vietnam

${ }^{2}$ Ho Chi Minh City University of Technology (Hutech), Vietnam

"Corresponding authors' emails: mynhu0503@gmail.com

(i) https://orcid.org/0000-0003-3172-6405

do) https://doi.org/10.54855/ijte.222112

Keywords: high school, computerbased activities, Computer-Assisted Language Learning, English speaking, communication
It is well-acknowledged that the English language is becoming widespread worldwide, and the application of computer technology in teaching and learning foreign languages in general and English, in particular, has shown significant changes. To improve English speaking skills for high school students, we designed and applied some computer-based activities (CBA) using computer technology. This research aimed to explore the effects of using such CBA in teaching English speaking at a high school in Ho Chi Minh City, Vietnam. The study was carried out with a mixture of quantitative and qualitative methods. A total of 88 high school students were engaged as subjects in the form of experimental and control groups. The experimental group was given a treatment using CBA in their speaking sections for five months. A set of pre-test and post-test was conducted to assess the effectiveness of CBA on this experimental group in comparison with the control one who got no treatment with CBA. In the assessment, we employed the form of PET speaking and this international test's speaking rubric and a student questionnaire which helped to identify the experimental students' attitudes towards CBA. The results showed the positive effects of using CBA on students' speaking skills and significantly improving their communication problems after treatment. In addition, they were quite interested in using $\mathrm{CBA}$, which is a great encouragement to recommend more use of $\mathrm{CBA}$ in teaching speaking to students in Vietnam's high schools and similar contexts.

\section{Introduction}

In the past, foreign language learning methods focused on learning grammar rules, describing sentence patterns, memorizing words, and interpreting text sources. However, with the trend of international economic integration, Vietnam has introduced several foreign languages, 
especially English, into the curricula at high school. English is also considered the language of international communication. Seidlhofer $(2011$, p. 20) also emphasizes that English is a unique language that has spread worldwide and describes the use of the English language "as a global means of inter-community communication." Some researchers (Sundkvist \& Nguyen, 2020; Nguyen \& Ngo, 2021; Quoc et al., 2021) have previously asserted that English is the most common language used and taught in Vietnam due to transnational trade and tourism and globalization. Thereby, it can be seen that English has become not only an important language of communication in different international communication contexts but also one of the main subjects taught in Vietnam's high schools.

On the other hand, the development of technology also plays a meaningful role in language learning. Many improvements in form, especially renewing the method of teaching English by applying the achievements of information technology such as the use of computers in education, have become indispensable. Chau (2021) stated that information technology has a positive and effective impact on improving students; speaking skills. Therefore, introducing computers into language learning has a long and varied history in many countries, and Vietnam is not an exception. It has been known for its various abbreviations, from computer-based training (CBT) to computer-assisted language learning (CALL). Teaching English using the computer as a specifically pedagogical tool help assist the appropriate instruction of English language learners.

Research by Ayres (2002) confirms that learners appreciate that the computer is really relevant in their learning, so CALL will help them have higher learning motivation. According to MuirHerzig (2004), the impact of the teaching and learning process is the application of technology in the classroom, and it will help teachers foster a constructive classroom environment. Jarvis and Achilleos (2013) also state that CALL is the best way to advance students' knowledge in second language learning. All indicate that we are using computer-based activities more and more.

Rather than trade and transactions, technology is heavily exploited in the educational sphere. Technology is a communication method. In order to communicate, learners must cultivate their speaking skills while learning English. Therefore, foreign language teaching programs have focused much on communication ability. With advances in multimedia technology, the Industrial Revolution 4.0 has had a significant impact on foreign language teaching and learning, contributing to diversifying and improving the efficiency of transferring foreign language knowledge and skills through the application of achievements of information technology, especially in teaching speaking skills. Teachers may organize exciting and lively CBA to improve learners' speaking competence. Therefore, it is required that teachers of foreign languages be equipped with the knowledge and the ability to apply information technology in their teaching. Teachers need to have the necessary knowledge in applying computers and handling them to promote the positive effects of computers in teaching (Burns, 2010). In most high schools in Vietnam, English speaking as a communication skill is a genuine hurdle that both teachers and students must overcome. Realizing the importance of communicating in 
English, the purpose of this study is to find out the effects of the classroom instructional use of CBA for speaking sections at a high school to help students improve their speaking competence and further improve the effective teaching using advantages of the time of technology 4.0 in Vietnam's English education context at high schools.

Moreover, global high school systems are aiming to "integrating technology" into teaching. Foreign language learning is expanding the use of technology by CALL to teach a second language (L2) related to speaking competence which is one of the elementary worries of language teachers. The appearance of technology has revolutionized language usage. In order to develop speaking abilities in classrooms, a variety of novel technologies are being demonstrated. CBA is well-used and contributes to the four skills of reading, writing, listening, and speaking with foreign language teachers and students from around the world. With the development of the Internet, the computer has been changed from a search tool and turned information into a useful and informative tool. The simultaneous global communication supported by the Internet has transformed the way teachers and students teach and learn a foreign language. In spite of the fact that technology cannot replace a teacher's critical function, it can be utilized to improve classroom teaching approaches. The Internet, podcasts, video conferencing, voice and video recognition software, TELL, and blogs are compared as the best tools for imparting communication skills. Besides, additional solutions such as linguistics laboratories or tape-based self-study, the integration of audio, voice interaction, text, video, and animation have replaced the methods, which have enabled teachers to create a lively learning environment and enhance the model of language learning in the classroom.

\section{Definition of key terms}

Computer: According to the views of two educators, Warschauer and Healey (1998), computers could help meet the needs and challenges of students' learning practice thanks to a variety of computer-based activities. In this study, the computer is a tool to design CBA in teaching English speaking. Students use computers to connect to the Internet and social networking sites such as Facebook, Skype, Line, Twitter, Viber, WhatsApp, etc. to practice speaking English. Fouz-González (2017) asserted that Twitter helps students improve pronunciation.

Computer-based activity: In this study, most activities were designed and framed by the curriculum so that the teacher could influence actual computer use in education. A computeraided learning environment would provide learners with an authentic learning environment that helped learners learn English better than in everyday classroom settings. In an article by Chirimbu and Tafazoli (2013), they affirmed that the process of language teaching and learning in a technology-based English classroom brought many valuable interactive opportunities for learners than in classrooms with traditional language learning.

Alkash and Al-Dersi (2017) stated that PowerPoint presentation provides users with tools to create interactive lessons, especially helping teachers and students in teaching and learning in a dynamic environment, etc. Using PowerPoint software to insert different audio, visual and audio-visual features into speaking lessons will help students easily grasp lesson information 
and achieve effective high interactive results, improving students' English speaking skills (Alkash, \& Al-Dersi, 2017).

\section{Literature review}

\section{Speaking competence}

Brown and Yule (1983, p.14) defined "Speaking is to express the needs - request, information, service, etc." In Oxford Advanced Learner's Dictionary, Hornby (2000, p. 1063), speaking is described as to talk or say something about something. In addition, Jones (2001, p. 155) stated, "Speaking is a form of communication". These definitions show that people spend of their everyday life in speaking to each other as communicating with each other. Online Merriam Webster's Dictionary (2004) defined speaking competence as the knowledge that enables a person to communicate and understand a language.

Savignon (1991, p. 267) emphasized in communication competence, understanding the sociocultural contexts of language use is essential for speaking skills. Similarly, according to Bachman and Palmer (1996, p. 371), one's speaking competence of a language is manifested by his/her linguistic competence, knowledge of encountering linguistic communication challenges, as well as linguistically emotional reactions. Additionally, Tran (2021) defined a person considered a proficient communicator when speaking competence is proficient.

In an article by Nunan (1999), the ability to speak a language is the ability to master enough vocabulary and structure to talk about some issue. Ginkel, Gulikers, Biemans, and Mulder (2015) stated that mastery of speaking via presentation is recognized as a fundamental ability of well-educated students. Afrizal (2015) emphasized by interacting through speaking activities in the information gap, the students feel comfortable communicating to create and receive information to improve their speaking competence in class. Also, Uchihara and Saito (2016) affirmed there is a close relationship between vocabulary and speaking skills because effective vocabulary usage shows the level of fluency of language learners.

In this research, the term "speaking competence" refers to a student who is able to speak coherently and with understanding other speakers and what they are saying about any given topic. It means that a student can speak English to others, so he/ she can achieve a certain degree of spoken interaction and spoken production. In reality, one's speaking competence depends on what context he/she is speaking in, e.g., a talk, a friendly conversation, or a presentation. As a result, it is the teacher who should create relevant activities and provide his/her students with as many chances as possible to improve their speaking skills in class. Murphy (1991) confirmed that language teachers should integrate speaking and listening and pronunciation teaching; reading and writing activities should be used as follow-up activities to encourage speaking competence. Oradee (2012) delined some communicative activities in language learning, such as discussion and role-play, play a crucial role in increasing students' English speaking skills. 


\section{Assessment criteria for speaking competence}

In this research, to measure the improvement of the student participants' speaking skills, the researcher applies the speaking performance assessment and the levels in Spoken Interaction and Spoken Production by Council of Europe (2018) as required in the Common European Framework of Reference for Languages (CEFR). It is a framework currently employed to measure students' English competence at high schools and universities in Vietnam. Here we focus on level B1, equal to PET for high school students at grade 10 in Vietnam as a set of assessment standards for their speaking competence.

Table 1. Assessing Speaking Performance - Level B (UCLES 2019, p.2)

\begin{tabular}{|c|c|c|c|c|}
\hline B1 & Grammar and Vocabulary & Discourse Management & Pronunciation & Interactive Communication \\
\hline 5 & $\begin{array}{l}\text { Shows a good degree of } \\
\text { control of simple } \\
\text { grammatical forms, and } \\
\text { attempts some complex } \\
\text { grammatical forms. } \\
\text { Uses a range of appropriate } \\
\text { vocabulary to give and } \\
\text { exchange views on familiar } \\
\text { topics. }\end{array}$ & $\begin{array}{l}\text { Produces extended } \\
\text { stretches of language } \\
\text { despite some hesitation. } \\
\text { - Contributions are relevant } \\
\text { despite some repetition. } \\
\text { Uses a range of cohesive } \\
\text { devices. }\end{array}$ & $\begin{array}{l}\text { Is intelligible. } \\
\text { - Intonation is generally } \\
\text { appropriate. } \\
\text { - Sentence and word stress is } \\
\text { generally accurately placed. } \\
\text { - Individual sounds are } \\
\text { generally articulated clearly. }\end{array}$ & $\begin{array}{l}\text { - Initiates and responds } \\
\text { appropriately. } \\
\text { Maintains and develops the } \\
\text { interaction and negotiates } \\
\text { towards an outcome with } \\
\text { very little support. }\end{array}$ \\
\hline 4 & \multicolumn{4}{|c|}{ Performance shares features of Bands 3 and 5 . } \\
\hline 3 & $\begin{array}{l}\text { Shows a good degree of } \\
\text { control of simple } \\
\text { grammatical forms. } \\
\text { Uses a range of appropriate } \\
\text { vocabulary when talking } \\
\text { about familiar topics. }\end{array}$ & $\begin{array}{l}\text { - Produces responses which } \\
\text { are extended beyond short } \\
\text { phrases, despite hesitation. } \\
\text { Contributions are mostly } \\
\text { relevant, but there may be } \\
\text { some repetition. } \\
\text { - Uses basic cohesive } \\
\text { devices. }\end{array}$ & $\begin{array}{l}\text { - Is mostly intelligible, and has } \\
\text { some control of phonological } \\
\text { features at both utterance and } \\
\text { word levels. }\end{array}$ & $\begin{array}{l}\text { - Initiates and responds } \\
\text { appropriately. } \\
\text { Keeps the interaction going } \\
\text { with very little prompting and } \\
\text { support. }\end{array}$ \\
\hline 2 & \multicolumn{4}{|c|}{ Performance shares features of Bands 1 and 3 . } \\
\hline 1 & $\begin{array}{l}\text { Shows sufficient control of } \\
\text { simple grammatical forms. } \\
\text { Uses a limited range of } \\
\text { appropriate vocabulary to } \\
\text { talk about familiar topics. }\end{array}$ & $\begin{array}{l}\text { Produces responses which } \\
\text { are characterised by short } \\
\text { phrases and frequent } \\
\text { hesitation. } \\
\text { Repeats information or } \\
\text { digresses from the topic. }\end{array}$ & $\begin{array}{l}\text { - Is mostly intelligible, despite } \\
\text { limited control of phonological } \\
\text { features. }\end{array}$ & $\begin{array}{l}\text { Maintains simple } \\
\text { exchanges, despite some } \\
\text { difficulty. } \\
\text { Requires prompting and } \\
\text { support. }\end{array}$ \\
\hline 0 & \multicolumn{4}{|c|}{ Performance below Band 1 . } \\
\hline
\end{tabular}

Source: https://www.cambridgeenglish.org/exams-and-tests/cefr/

The B1 scales are divided into six bands from 0 to 5 , with 0 being the lowest and 5 the highest. Descriptors for each criterion indicate what a candidate is expected to demonstrate at each band. Usually, students who achieve band 3 and above generally get at least B1 level. Thanks to such detailed descriptors, teachers can observe how students carry out their speaking tasks, note down examples of performance related to the listed criteria, give students feedback on their strengths and weaknesses, and evaluate whether students are able to achieve level B1 and how they could improve.

In high schools, teaching English speaking is directing students to band 3 and above. Therefore, all speaking activities should be designed to help students meet these criteria. The teacher constantly explores and creates many learning activities to create a learning and fun space to encourage students to interact efficiently, sharpen communication skills, and feel comfortable and excited about learning. Thus, the use of the computer with various photo and video activities relevant to what students are learning help the teacher enable to make his/ her English-speaking classes more vivid as well as get them familiar with the B1 speaking tasks, most of which use pictures, photographs or other visuals as a stimulus for interaction. 


\section{Computer-assisted language learning in classrooms}

Many scholars, consisting of Levy (1977, p. 1), affirmed that computer-assisted language learning is widely described as exploring and investigating applications of the computer in teaching and learning a language. CALL has a positive impact on student achievement. As a result, the computer plays an important role in active learning and advanced thinking. Warschauer and Kern (2000) agreed that the computer is a great support tool that benefits teaching and learning when it is used in a context with a specific purpose. Pearcey and Elliott (2004) argued that an essential key role to continuous learning is creating a supportive environment for students and opportunities for students to engage in activities. This means the computer-based learning environment is quite helpful.

Also, Bai (2009) indicated that the attitude of university students in China towards CALL is quite positive in their learning English as a foreign language. Similarly, Genç and Aydin (2011) emphasized that students are more motivated, creative and improve their academic performance if taught in a computer-based environment. Prince (2017) suggested that integrating technology into the English language classroom increases student engagement as well as cognitive and learning development. Therefore, the use of CALL in classrooms is of great importance and a certain trend in language teaching in the world, and Vietnam is not an exception.

\section{Computer-based activities}

In a classroom with computer-based activities, the learning environment is primarily studentcentered rather than a teacher-centered model, and learning is highly interactive, then the student engagement increases. As Haitao (2011), pointed out the importance of a studentcentered model in a computer-based English teaching classroom.

Many researchers indicate that students have a stronger motivation to learn English in a computer-based learning environment than in a learning environment without a computer (Arkın, 2003; Marco, 2002; Uzunboylu, 2004). Students improved their learning motivation and increased their willingness to study language studies when learning with computers. According to Little (2007), many researchers have highly appreciated creating an atmosphere in which student autonomy and self-determination principles are consistent with the CALL context (Blin, 2004; O'Dowd, 2007; Schwienhorst 2008; Guillén, 2014). They all agreed that the nexus between technology and the use of language in the modern world would change thinking about how computer-based technology is changing the teaching of English. To increase learners' communicative competence, the learners need to practice using English frequently in the classroom, particularly in an English language class with the help of the computer with a very vibrant and bustling learning atmosphere. When the activities are designed very vividly and attractively, students actively participate in learning. This is the reason why technology is quite relevant to changes in English language teaching, and computer-based activities are not strange for English language teachers. The fact that the presence of the computer and the interaction with it require students to use English, meaning that the English they use is somehow shaped or influenced by the computer technology. Thus, this study would consider and focus 
on the language demands for proficient use of English in a computer-assisted classroom to design activities for the speaking class.

\section{Common computer-based activities in teaching English speaking}

Below is a summary of some common CBA that has been designed based on the common IT on the computer and their benefits in an English-speaking class.

\begin{tabular}{|c|c|c|}
\hline Order & $\begin{array}{c}\text { Kinds of computer-based } \\
\text { activities }\end{array}$ & Importance of CALL/ Benefits \\
\hline 1. & $\begin{array}{l}\text { PowerPoint/ ActivInspire (with } \\
\text { inserting video clips, animations, } \\
\text { sounds, a lesson with colorful } \\
\text { text). }\end{array}$ & $\begin{array}{l}\text { - Help the instructor save time writing on a chalkboard } \\
\text { (Alkash, \& Al-Dersi, 2017). } \\
\text { - Attract and maintain learners' attention (Alkash, \& Al- } \\
\text { Dersi, 2017). } \\
\text { - Help learners see and interact well with the lesson } \\
\text { (Alkash, \& Al-Dersi, 2017). } \\
\text { - Improve presentation skills (Alkash, \& Al-Dersi, 2017). }\end{array}$ \\
\hline 2. & $\begin{array}{l}\text { Internet software (with many } \\
\text { English study programs) }\end{array}$ & $\begin{array}{l}\text { - Help learners have the opportunity to successfully use } \\
\text { English through online software on the Internet such as } \\
\text { Google to search for suitable learning materials (Parveen, } \\
\text { 2016). } \\
\text { - Help students actively participate in Internet-based } \\
\text { learning activities and be motivated to practice English in } \\
\text { language classrooms (Chairat, 2018). }\end{array}$ \\
\hline 3. & $\begin{array}{l}\text { Google translation tool, online } \\
\text { dictionaries }\end{array}$ & $\begin{array}{l}\text { - Help learners increase their vocabulary and reading } \\
\text { comprehension (Hulstijn, Holander, \& Greidanus, 1996; } \\
\text { Luppescu \& Day, 1993). } \\
\text { - Be free, quickly accessible, and easy to use (Ngoc, 2017). } \\
\text { - Help students discern the semantics of words and ensure } \\
\text { a reliable translation (Medvedev, 2016). }\end{array}$ \\
\hline 4. & $\begin{array}{l}\text { Speech teaching software such as } \\
\text { HelloTalk, Cake, Duolingo, } \\
\text { SpeakingPal, Enjoy. }\end{array}$ & - Help students pronounce clearly (O’Brien, 2006). \\
\hline 5. & Communication lab & $\begin{array}{l}\text { - Help students to develop four skills (Parveen, 2016). } \\
\text { - Create interest in learning for students through } \\
\text { headphones in the laboratory (Parveen, 2016; Kuning, } \\
\text { 2019). }\end{array}$ \\
\hline 6. & Video conferencing & $\begin{array}{l}\text { - Give students a chance to communicate directly with } \\
\text { many famous people in the world (Parveen, 2016' Kuning, } \\
\text { 2019). } \\
\text { - Expand more knowledge in many different fields } \\
\text { (Parveen, 2016). }\end{array}$ \\
\hline 7. & Speech recognition software & $\begin{array}{l}\text { - Be capable of automatic assessment of pronunciation } \\
\text { quality Neumeyer, Franco, Digalakis, and Weintraub, } \\
\text { 2000). } \\
\text { - Help students to find the pronunciation errors to improve } \\
\text { their speaking (Kuning, 2019). } \\
\text { - Promote students to practice many times until they are } \\
\text { proficient and fluent as desired (Parveen, 2016). }\end{array}$ \\
\hline
\end{tabular}


Obviously, various CBA can be designed and applied for language classes. Many researchers, as mentioned above, affirm how effective use of the computer could change the nature of classroom teaching and learning.

\section{Research questions}

This study aims at exploring the effects of using CBA in teaching English speaking at a high school in Ho Chi Minh City in Vietnam, and the following research questions are addressed:

1. What are the effects of using CBA in teaching English speaking at a high school?

2. What are the students' attitudes towards the use of CBA in learning English speaking at this high school?

\section{Methods}

\section{Research design}

This research is an experimental study conducted in a High School, Ho Chi Minh City. The researcher intended to conduct this study at work, right at the beginning of the school year after being assigned to teach two $10^{\text {th }}$ graders, the researcher chose one of these two $10^{\text {th }}$ graders to conduct the CBA application and use the computer to design English teaching activities speaking at school. Until the second semester, the researcher officially started the research.

In this study, quantitative research collected the score data from the pre-speaking and postspeaking test and the results of a student survey questionnaire to explore the effects of using CBA in teaching English speaking at a High School. The two speaking tests and a questionnaire were analyzed using statistical analysis software SPSS, an essential and reliable tool for the researcher to evaluate the improvement of learners' speaking skills accurately. According to Muijs (2004), empirical research aims to be carried out to prove a known factor to test the validity of a hypothesis.

Moreover, a survey questionnaire design was used to measure the students' attitudes towards the use of CBA in learning English speaking at a High School with statistical precision.

Muijs (2004) distinguishes that the experimental design comprises two main groups: the control and experimental groups. The subjects participating in the experimental group will receive the experimental treatment, and the control group will not. Therefore, based on the results of the pre-speaking test, the researcher divided the $10^{\text {th }}$ graders into two study groups: the experimental group (Green Class) and the control group (Yellow Class).

\section{Sample and sampling procedures}

The subjects of the study were $10^{\text {th }}$-grade students at a high school in Ho Chi Minh City, Vietnam. The participants were chosen because they have learned English for many years, and they all studied with the same Vietnamese and foreign teachers in both classes Yellow Class and Green Class. They were chosen by convenient sampling. After, the 88 students of two 
English classes attended a speaking test assessed by a native teacher, using the criteria for PET speaking test as mentioned above. The score results were collected, and then one of the two $10^{\text {th }}$ grade classes - Green Class - was randomly selected for treatment with CBA.

The $10^{\text {th }}$-grade students had just moved from their secondary schools to this high school and were eager to discover new styles of learning. They are still in a stage of self-consciousness and are able to concentrate on one activity for more extended periods than previously in their secondary schools but still need interaction and variety. They are typical representatives of generation $\mathrm{Z}$ who are in favor of new technologies. Significantly, they prefer to reason and consider diverse points of view. Thus, exploring their adaption and attitudes towards using CBA in their classrooms is quite advantageous. And the research findings are expected to be useful for those who want to find out fresh ideas and gain more experience in using CBA to improve students' English speaking at high schools in Vietnam.

The researcher used the English Textbook 10 by the Vietnamese Education publisher, $4^{\text {th }}$ edition, which consists of 16 units. Each unit has five parts, including reading comprehension, speaking, listening, writing, and language focus. In addition, each semester has eight units and eight different speaking topics. In the second semester, the $10^{\text {th }}$-grade students learn units 9-16. The CBA applied in accordance with the speaking theme for the eight units were designed and presented fully. Each lesson lasts 45 minutes and starts at the beginning of the second semester.

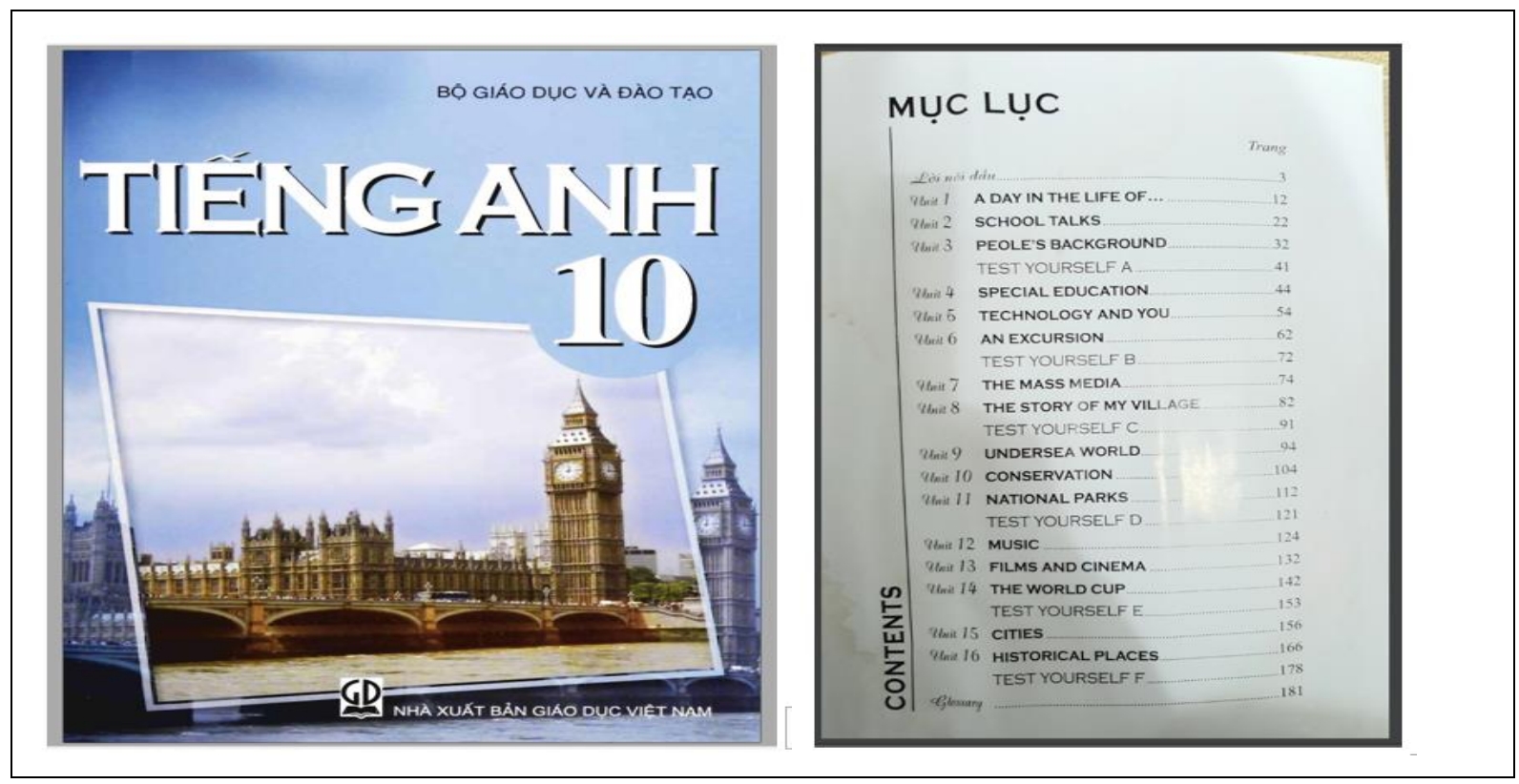

During the five months of the experiment, the two groups of $10^{\text {th }}$ grade students were taught by the same instructor, i.e., the researcher, but with different treatments. The experimental group, i.e., Green Class, would be instructed and practiced improving their speaking competence by using CBA, while the control group, i.e., Yellow Class, received no instructions on using CBA. For the teaching procedure of the experimental group, there were all eight lessons in the 
textbook which were applied CBA to enhance the students' English speaking skills in the second semester. For each lesson with a specific speaking topic, the instructor used a computer for designing and applying one of the six common CBA types as mentioned in the Literature review.

Their positive attitudes can be found in Figure 1 below, in which students were quite excited in CBA in their class with the good classroom atmosphere and effective group presentations.

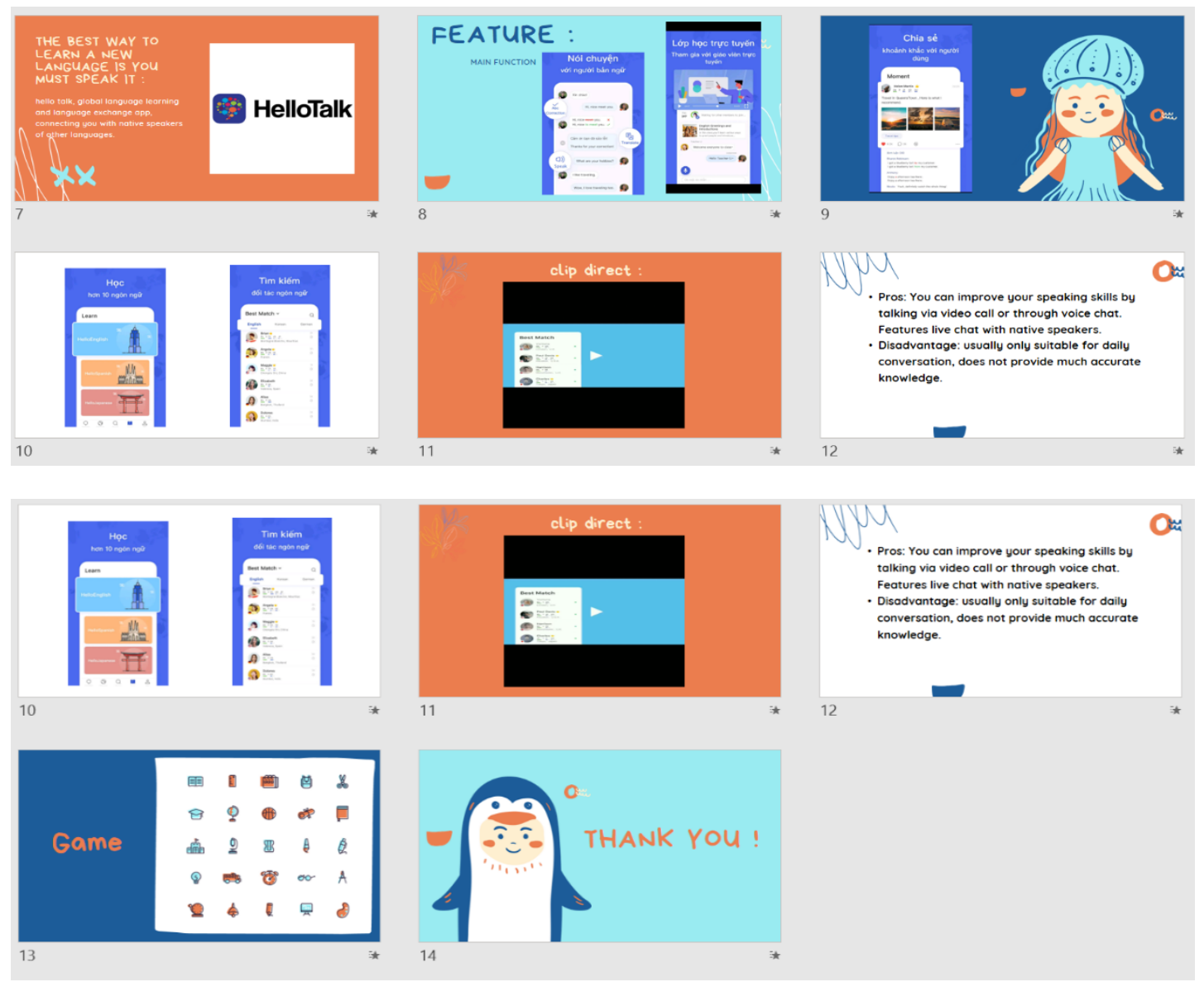

Figure 1. Group 1 's presentation in Green Class in which they designed some games and applied the speaking technology software called HelloTalk to practice speaking

\section{Research instruments}

In this study, the researcher would apply a pre-speaking test and post-speaking test, a questionnaire as research instruments. In the post-speaking test, the participants were asked the same questions as the pre-test and covered some new topics such as food, special holidays, the environment, movies. The speaking test lasted for 150 minutes. Also, the researcher used mobile phones to record students' presentations and used a PET speaking rubric to assess the results of the students' improvement in communication. 


\section{(1) Pre-speaking test and post-speaking test}

The pre-test was conducted with two $10^{\text {th }}$ grade classes, consisting of simple questions posed by a native teacher (self-introduction, hobbies, daily routines, etc.), using common topics as suggested in PET speaking tests. Then the native teacher graded and sent the score list back to the instructor to store as data for the research. However, instead of the scales of 6 bands by CEFR, we modified these 6 scales into 10 as required in Vietnam's scoring education system. That means 0-1(band 0), 2-3 (band 1), 3-4 (band 2), 5-6 (band 3), 7-8 (band 4), 9-10 (band 5).

After the experiment, the post-test was given to see how the test results of the two groups improved. And the particular purpose was to see whether the scores of the experimental group in the post-speaking test compared to the pre-speaking test have enhanced or not.

Moreover, the post-test was conducted to confirm and evaluate the effectiveness of using CBA and measure the learners' improvement in English speaking. While the native teacher was testing the students' post-speaking test, the researcher recorded the students' speaking tests. After getting the scores of the post-test from the native teacher, the researcher used PET speaking rubric to assess more their speaking performance. In the post-speaking test, the participants were asked the same questions as the pre-test and covered some new topics such as food, special holidays, the environment, movies so that the teacher could measure their improvement if any. Both speaking tests are scored by the same native teacher. The researcher only collected the results and conducted a comparison of the students' progress in speaking ability in the two groups.

\section{(2) Student questionnaire}

The questionnaire was delivered to the experimental group to collect their perspectives and answers after treatment in this current study. It aimed to investigate their feelings about their computer use and attitudes towards the advantages of using computer-based activities in support of their teacher's teaching English speaking.

The survey questionnaire is on a 6-point Likert scale. It was used to measure the experimental group's opinions about CBA, and the scale was given and ranked in order from 1 lowest point to 6 highest score; and the survey was conducted in 45 minutes. In detail, the scale of possible responses to the question - ranged from 1 (strongly disagree) through 3 (neither disagree nor agree) to 6 (strongly agree). The questionnaire was developed from Stepp-Greany (2002) and Rahimi (2011). In respect to its structure, the questionnaire covered twenty-two statements divided into two groups: (1) the effects of using computer-based activities in teaching English speaking (from questions 1 to 14) and (2) students' attitudes towards their teacher's instruction with CBA in an English-speaking section (from questions 15 to 22). These statements elicited information about the students' effectiveness as well as attitudes towards learning English Speaking through CBA. 


\section{Data collection procedures}

The data collection was done from January to May 2021, including four steps as follows.

Step 1: The score data was collected via a pre-speaking test assessed by a native teacher. A pretest was a procedure to show the initial score results of the Yellow Class and Green Class students before applying CBA in class. All the students' answers were recorded for later use. The implementation start date was in January 2021, when students began the $2^{\text {nd }}$ semester. After that, the researcher saved the score results for comparison after the course finished.

Step 2: Green Class with 43 students was selected as the experimental group for computerbased instruction through eight units, using CBA to enhance the students' English-speaking competence; and the students in Yellow Class served as the control group, learning without any CBA treatment. CBA was used in various forms for the experimental group for each unit in the second semester.

Step 3: At the end of the course and before the students took the $2^{\text {nd }}$-semester exam in May 2021, the same native teacher was invited to give the experimental group and the control group a post-speaking test to collect the score data and compare if there were any differences between pre-test and post-test. The students' answers were also recorded for further analysis.

Step 4: The experimental group was invited to participate in a questionnaire survey written both in English and Vietnamese about the CBA designed for their treatment. It was conducted for 45 minutes. At the beginning of the survey, the participants were thoroughly explained about the objective of the questionnaire and its items so that they could understand clearly and with full collaboration. Then the collected data was analyzed by using SPSS software.

The questionnaire was developed from those used in some previous researches, including Stepp-Greany, 2002; Rahimi, 2011; and Pham Ngoc Truong Linh, 2017.

The reliability of the data refers to the accuracy or truthfulness of measurement of the results for the current study. In terms of the questionnaire-based survey, since the questionnaire is based on some items that many researchers used in their studies have used (some content has also been adapted to the current study), a certain degree of validity (both structural and content validity) can be assumed immediately from the beginning.

\section{Results and discussions}

Research question 1: What are the effects of using CBA in teaching English speaking to grade $10^{\text {th }}$ students at Binh Hung Hoa High School?

\section{(1) Results and discussions from the pre-speaking test and post-test speaking}

The comparison of the score results of the pre-speaking test and post-speaking test of the experimental and control groups is presented in Table 2 and Table 3.

For the pre-test, it can be seen that the students earned the highest pre-test score of 8 points 
and the lowest of 3 points. These results show that students still had limited English speaking competence in both groups. The percentage of students with an average score from 6 in the experimental group was about $50 \%$, while that of the control group was about $80 \%$.

However, there is a really positive change in the score of the post-test. The results in Table 3 indicate that the experimental group students achieved the highest speaking score of 10 points and the lowest of 6 points. No student scores were below average as before. Students have greatly improved their English-speaking competence. For the control group, the highest score achieved by the student was 9 , and no 10 was found. The percentage of the students with an average score from 6 in the control group was nearly $85 \%$ in comparison with $80 \%$ of the pretest. It means there is not much change in this group.

Table 2. The pre-test and post-test scores of the experimental group

\begin{tabular}{|c|c|c|c|c|c|c|c|c|c|c|c|}
\hline \multicolumn{6}{|c|}{ Pre-test (Experimental group) } & \multicolumn{6}{|c|}{ Post-test (Experimental group) } \\
\hline & & Frequency & Percent & Valid Percent & $\begin{array}{c}\text { Cumulative } \\
\text { Percent } \\
\end{array}$ & & & Frequency & Percent & Valid Percent & $\begin{array}{l}\text { Cumulative } \\
\text { Percent }\end{array}$ \\
\hline \multirow[t]{7}{*}{ Valid } & 3 & 1 & 2.3 & 2.3 & 2.3 & \multirow[t]{7}{*}{ Valid } & 6 & 2 & 4.7 & 4.7 & 4.7 \\
\hline & 4 & 2 & 4.7 & 4.7 & 7.0 & & 7 & 11 & 25.6 & 25.6 & 30.2 \\
\hline & 5 & 18 & 41.9 & 41.9 & 48.8 & & 8 & 16 & 37.2 & 37.2 & 67.4 \\
\hline & 6 & 14 & 32.6 & 32.6 & 81.4 & & 9 & 11 & 25.6 & 25.6 & 93.0 \\
\hline & 7 & 6 & 14.0 & 14.0 & 95.3 & & & , & & & \\
\hline & 8 & 2 & 4.7 & 4.7 & 100.0 & & 10 & 3 & 1.0 & 1.0 & 100.0 \\
\hline & Total & 43 & 100.0 & 100.0 & & & Total & 43 & 100.0 & 100.0 & \\
\hline
\end{tabular}

Table 3. The pre-test and post-test scores of the control group

\begin{tabular}{|c|c|c|c|c|c|c|c|c|c|c|c|}
\hline \multicolumn{6}{|c|}{ Pre-test (Control group) } & \multicolumn{6}{|c|}{ Post-test (Control group) } \\
\hline & & Frequency & Percent & Valid Percent & $\begin{array}{c}\text { Cumulative } \\
\text { Percent }\end{array}$ & & & Frequency & Percent & Valid Percent & $\begin{array}{l}\text { Cumulative } \\
\text { Percent }\end{array}$ \\
\hline \multirow[t]{7}{*}{ Valid } & 3 & 1 & 2.2 & 2.2 & 2.2 & \multirow[t]{7}{*}{ Valid } & 4 & 2 & 4.4 & 4.4 & 4.4 \\
\hline & 4 & 1 & 2.2 & 2.2 & 4.4 & & 5 & 4 & 8.9 & 8.9 & 13.3 \\
\hline & 5 & 8 & 17.8 & 17.8 & 22.2 & & 6 & 14 & 31.1 & 31.1 & 44.4 \\
\hline & 6 & 19 & 42.2 & 42.2 & 64.4 & & 7 & 15 & 33.3 & 33.3 & 77.8 \\
\hline & 7 & 9 & 20.0 & 20.0 & 84.4 & & 8 & 8 & 17.8 & 17.8 & 95.6 \\
\hline & 8 & 7 & 15.6 & 15.6 & 100.0 & & 9 & 2 & 4.4 & 4.4 & 100.0 \\
\hline & Total & 45 & 100.0 & 100.0 & & & Total & 45 & 100.0 & 100.0 & \\
\hline
\end{tabular}

Besides, the focus of this study is a mainly in-depth analysis of the experimental group's results through pre-test and post-test to demonstrate that the use of CBA is effective in the English- 
speaking classroom. Thus, the results of the speaking test of the control group served as a stepping stone for the analysis of the experimental group. At the same time, it is a prerequisite for developing a more effective experimental group.

The findings above are quite similar to those in the study of AL-Garni and Almuhammadi (2019). These researchers succeeded in testing the effect of using communicative language activities on the speaking skills of EFL students at the University of Jeddah by comparing the score results of the experimental and control groups. Research results also showed that the scores of the pre-test and post-test of the experimental group were higher than those of the control group, especially shown clearly by the difference between the median values. Using SPSS software, the study showed that the median of the total scores of the post-test increased by 1.500 compared to the pre-test in the experimental group, which proved that the students had enhanced their speaking skills. Besides, the scores of the pre-test and post-test of the control group did not change after the experiment. The median of the total scores remained the same as the original 3.0.

Based on the recording of the speaking test of the post-test and the score results, the researcher used the PET speaking rubric as mentioned in the Literature Review to analyze the improvement in English speaking of the student participants. The results showed that the students in the experimental group knew more vocabulary, understood the topic content, provided good main ideas to answer the examiner's questions, and performed their speaking with more fluency. In detail, the students could arrange sentences in appropriate grammatical orders, and they found it easy to understand the examiner and communicate effectively; they were able to listen and grasp the preliminary information and then responded with good interaction; their pronunciation was more precise, more confident with intonation better than before; and they could use words and phrases flexibly in short conversations. The scores are strong evidence for their improvement of communication performance in the post-test in respect to all the four assessment criteria of the PET speaking test. 


\section{(2) Results and discussions from the student questionnaire}

Questions 1 to 14 in the questionnaire are for further discovering the effects of CBA in teaching English speaking.

Table 4. The effects of CBA in the students' English-speaking performance

\begin{tabular}{|c|c|c|c|c|c|c|}
\hline Opinions about CBA & $\begin{array}{l}\text { Strongly } \\
\text { disagree }\end{array}$ & Disagree & $\begin{array}{c}\text { Slightly } \\
\text { disagree }\end{array}$ & $\begin{array}{c}\text { Slightly } \\
\text { agree }\end{array}$ & Agree & $\begin{array}{c}\text { Strongly } \\
\text { agree }\end{array}$ \\
\hline $\begin{array}{l}\text { 1- I find that the instructions of CBA are } \\
\text { easy to understand. }\end{array}$ & $2,3 \%$ & $4,7 \%$ & $2,3 \%$ & $7 \%$ & $11,6 \%$ & $72,1 \%$ \\
\hline $\begin{array}{l}\text { 2- I find that CBA are easy to take part } \\
\text { in. }\end{array}$ & $2,3 \%$ & $7 \%$ & $2,3 \%$ & $7 \%$ & $25,6 \%$ & $55,8 \%$ \\
\hline $\begin{array}{l}\text { 3- I think that CBA require students to } \\
\text { interact with each other to practice } \\
\text { speaking. }\end{array}$ & $7 \%$ & $4,7 \%$ & $4,7 \%$ & $2,3 \%$ & $13,9 \%$ & $67,4 \%$ \\
\hline $\begin{array}{l}\text { 4- I understand the content conveyed in } \\
\text { CBA for speaking practice in the class. }\end{array}$ & $7 \%$ & $2,3 \%$ & $4,7 \%$ & $9,3 \%$ & $37,2 \%$ & $39,5 \%$ \\
\hline $\begin{array}{l}\text { 5- I can confidently communicate and } \\
\text { speak more fluently thanks to CBA. }\end{array}$ & $2,3 \%$ & $2,3 \%$ & $2,3 \%$ & $7 \%$ & $44,2 \%$ & $41,9 \%$ \\
\hline $\begin{array}{l}\text { 6- There are many effective CBA } \\
\text { (Google translation, HelloTalk, Cake, } \\
\text { Duolingo, SpeakingPal) in learning } \\
\text { English speaking. } \\
\text { - I think that CBA help me speak English } \\
\text { better. }\end{array}$ & $0 \%$ & $0 \%$ & $0 \%$ & $4,7 \%$ & $9,3 \%$ & $86 \%$ \\
\hline $\begin{array}{l}\text { 7- My language learning is improved } \\
\text { when I learn with CBA. }\end{array}$ & $0 \%$ & $2,3 \%$ & $4,7 \%$ & $7 \%$ & $46,5 \%$ & $39,5 \%$ \\
\hline $\begin{array}{l}\text { 8- I think that the contents from CBA are } \\
\text { helpful for my self-study. }\end{array}$ & $0 \%$ & $2,3 \%$ & $2,3 \%$ & $4,7 \%$ & $9,3 \%$ & $81,4 \%$ \\
\hline $\begin{array}{l}\text { 9- I find that CBA help me interact more } \\
\text { with my teacher. } \\
\text { - I find that CBA help me interact more } \\
\text { with my friends. }\end{array}$ & $0 \%$ & $2,3 \%$ & $4,7 \%$ & $0 \%$ & $27,9 \%$ & $65,1 \%$ \\
\hline $\begin{array}{l}\text { 10- I find that my speaking skills in } \\
\text { English improved as a result of the CBA. }\end{array}$ & $0 \%$ & $2,3 \%$ & $4,7 \%$ & $2,3 \%$ & $20,9 \%$ & $69,8 \%$ \\
\hline $\begin{array}{l}\text { 11- I gain more confidence in English } \\
\text { language activities after using CBA. }\end{array}$ & $2,3 \%$ & $2,3 \%$ & $4,7 \%$ & $2,3 \%$ & $37,2 \%$ & $51,2 \%$ \\
\hline $\begin{array}{l}\text { 12- I think that CBA help students to } \\
\text { improve their knowledge of vocabulary, } \\
\text { pronunciation, and grammar, and so on. }\end{array}$ & $2,3 \%$ & $7 \%$ & $4,7 \%$ & $4,7 \%$ & $32,5 \%$ & $48,8 \%$ \\
\hline $\begin{array}{l}\text { 13- There are some effective speech } \\
\text { teaching software such as HelloTalk, } \\
\text { Cake, Duolingo, SpeakingPal, Enjoy, etc. } \\
\text { - The tasks I perform using CBA are } \\
\text { interesting (such as Cake, SpeakingPal } \\
\text { Software, etc.). }\end{array}$ & $0 \%$ & $0 \%$ & $2,3 \%$ & $4,7 \%$ & $20,9 \%$ & $72,1 \%$ \\
\hline $\begin{array}{l}\text { 14- I learn many things from the } \\
\text { interactive CBA. }\end{array}$ & $0 \%$ & $2,3 \%$ & $4,7 \%$ & $7 \%$ & $34,8 \%$ & $51,2 \%$ \\
\hline
\end{tabular}

The statistical results reveal that most of the students agreed on the positive impacts of CBA on their learning. Over $75 \%$ to $90 \%$ thought that CBA was beneficial and helped create more interaction in the learning process; the students learned a lot from CBA and made significant 
progress in their communication. In items 6 and 13, nearly $100 \%$ of the students enjoyed learning speaking with all the CBA designed for their speaking class because these CBA helped enhance their speaking competence. For the other items, over 85\%-90\% believed that using CBA in English speaking class would help them improve their knowledge of vocabulary and pronunciation and gain more confidence in communication. It means the use of CBA is quite effective in enhancing all the aspects of speaking performance, including grammar and vocabulary, discourse management, pronunciation and interactive communication.

Research question 2: What are the students' attitudes towards the use of CBA in learning English speaking at this high school?

Table 4. The students'attitudes towards the use of CBA in their English-speaking class

\begin{tabular}{|c|c|c|c|c|c|c|}
\hline Opinions about CBA & $\begin{array}{l}\text { Strongly } \\
\text { disagree }\end{array}$ & Disagree & $\begin{array}{c}\text { Slightly } \\
\text { disagree }\end{array}$ & $\begin{array}{c}\text { Slightly } \\
\text { agree }\end{array}$ & Agree & $\begin{array}{c}\text { Strongly } \\
\text { agree }\end{array}$ \\
\hline $\begin{array}{l}\text { 15- I like the learning environment } \\
\text { using CBA. }\end{array}$ & $0 \%$ & $0 \%$ & $4,7 \%$ & $9,3 \%$ & $23,2 \%$ & $62,8 \%$ \\
\hline $\begin{array}{l}\text { 16- I prefer learning English speaking } \\
\text { through CBA than learning English } \\
\text { speaking with traditional classroom } \\
\text { activities. }\end{array}$ & $0 \%$ & $2,3 \%$ & $2,3 \%$ & $7 \%$ & $9,3 \%$ & $79,1 \%$ \\
\hline $\begin{array}{l}\text { 17- I prefer the flexibility of being able } \\
\text { to do all CBA in the classroom. }\end{array}$ & $0 \%$ & $2,3 \%$ & $4,7 \%$ & $9,3 \%$ & $30,2 \%$ & $53,5 \%$ \\
\hline $\begin{array}{l}\text { 18- I enjoy interacting with others to } \\
\text { enhance speaking skills thanks to } \\
\text { CBA. }\end{array}$ & $2,3 \%$ & $0 \%$ & $4,7 \%$ & $9,3 \%$ & $18,6 \%$ & $65,1 \%$ \\
\hline $\begin{array}{l}\text { 19- It is very effective to use CBA to } \\
\text { design and organize pictures and } \\
\text { videos in an English language } \\
\text { classroom. } \\
\text { - I like the pictures and videos } \\
\text { enclosed in CBA. }\end{array}$ & $0 \%$ & $0 \%$ & $0 \%$ & $7 \%$ & $2,3 \%$ & $90,7 \%$ \\
\hline $\begin{array}{l}\text { 20- I put more time into CBA practice } \\
\text { speaking in a regular English class. }\end{array}$ & $0 \%$ & $2,3 \%$ & $2,3 \%$ & $7 \%$ & $25,6 \%$ & $62,8 \%$ \\
\hline $\begin{array}{l}\text { 21- I think that CBA should be } \\
\text { included in English lessons. }\end{array}$ & $2,3 \%$ & $2,3 \%$ & $2,3 \%$ & $4,7 \%$ & $27,9 \%$ & $60,5 \%$ \\
\hline $\begin{array}{l}\text { 22- I like using online dictionaries to } \\
\text { find information about word sounds } \\
\text { and practice speaking. }\end{array}$ & $0 \%$ & $0 \%$ & $0 \%$ & $4,7 \%$ & $25,6 \%$ & $69,7 \%$ \\
\hline
\end{tabular}

Items 15-22 show that the whole experimental group expressed a positive attitude towards the effective use of CBA in teaching English speaking skills. According to the results of the survey, the percentage of students agreeing is very high, accounting for about $85 \%$ or over. The results prove that the application of CBA in the classroom for the students at this high school is very reasonable and meets their communication needs. In-depth, 100\% of students like learning to speak English through CBA using pictures, videos, and online dictionaries. About 85\% expected the classroom environment with the use of CBA because they have more interaction and more practice than in the traditional classroom one. And over $80 \%$ supported and preferred the use of CBA in their speaking class. 
The students' attitudes towards the use of CBA in their English speaking sections

\begin{tabular}{|c|c|c|c|c|}
\hline & $\mathrm{N}$ & Sum & Mean & Std. Deviation \\
\hline $\begin{array}{l}\text { I like the learning } \\
\text { environment using CBA. }\end{array}$ & 43 & 234.00 & 5.4419 & .85363 \\
\hline $\begin{array}{l}\text { I prefer learning English } \\
\text { speaking through CBA } \\
\text { than learning English } \\
\text { speaking with traditional } \\
\text { classroom activities. }\end{array}$ & 43 & 241.00 & 5.6047 & .90342 \\
\hline $\begin{array}{l}\text { I prefer the flexibility of } \\
\text { being able to do all CBA } \\
\text { in the classroom. }\end{array}$ & 43 & 227.00 & 5.2791 & .98381 \\
\hline $\begin{array}{l}\text { I enjoy interacting with } \\
\text { others to enhance } \\
\text { speaking skills thanks to } \\
\text { CBA. }\end{array}$ & 43 & 231.00 & 5.3721 & 1.09160 \\
\hline $\begin{array}{l}\text { I like the pictures and } \\
\text { videos enclosed in CBA. }\end{array}$ & 43 & 251.00 & 5.8372 & .53141 \\
\hline $\begin{array}{l}\text { I put more time into CBA } \\
\text { practice speaking in a } \\
\text { regular English class with } \\
\text { traditional activities. }\end{array}$ & 43 & 234.00 & 5.4419 & .90770 \\
\hline $\begin{array}{l}\text { I think that CBA should be } \\
\text { included in English } \\
\text { lessons. }\end{array}$ & 43 & 230.00 & 5.3488 & 1.11021 \\
\hline $\begin{array}{l}\text { I like using online } \\
\text { dictionaries to find } \\
\text { information about word } \\
\text { sounds and practice } \\
\text { speaking. }\end{array}$ & 43 & 243.00 & 5.6512 & .57253 \\
\hline Valid N (listwise) & 43 & & & \\
\hline
\end{tabular}

Figure 3. Mean and standard deviation of the student's attitudes towards the use of CBA in their English speaking sections

The above descriptive statistics table details the mean values of 8 items related to the students' attitudes towards their teacher's using CBA in teaching English speaking. From the survey results of this questionnaire, the researcher can analyze the data to get the mean value above 5.2. From that, it is concluded that students have a positive attitude and highly appreciate the application of CBA to support students in speaking practice.

In Jin and Deifell' research (2013), the use and awareness of learners for online dictionaries shows the importance of online dictionaries in language courses. Online dictionaries help learners access and learn the meanings and forms of words and the pronunciation of words in listening and speaking tasks. In addition, the research findings pointed out that the use of online dictionaries such as Google Search and Google Translate did assist students' learning. This research's findings indicated clear resonance with previous studies because my findings show that the students really enjoyed learning English speaking through CBA with online dictionaries, Google Search, and Google Translate. These tools help students improve their pronunciation skills, leading to a positive learning attitude of students.

Through the questionnaire survey in this research, the students expressed their positive attitude towards the effective use of CBA in teaching and learning English speaking. 


\section{Conclusions and recommendations}

The present study's primary purpose is to explore the effects of using computer-based activities in teaching English speaking at a high school in Vietnam. At the same time, the study investigates the students' attitudes towards learning English speaking through CBA. To see the effectiveness of CBA, the researcher conducted three steps to collect the data and get the results: pre-test scores, post-test scores, and a survey questionnaire.

After five the experiment, the detailed results of scores of the pre-speaking and post-speaking tests show that students in the experimental group have excellent improvements in speaking competence. All of the students in Green Class (experimental group) got higher scores in the post-speaking test than in the pre-speaking test while in Yellow Class (control group), there was little change. Besides, in the control group, some students had an increase in scores, and some had a decrease in scores compared to baseline. The researchers relied on the PET speaking criteria to assess the students' level of English-speaking improvement. These findings support the effectiveness of using CBA in teaching English speaking to high school students.

In the present study, the researcher found that, in general, there is still a specific limit. The current study only focuses on exploring the effects of using CBA to better high school students' English speaking through applying CBA that are designed with the best information technology applications used on the computer for $10^{\text {th }}$ grade students, not all types of high school students. Therefore, its findings may not apply to larger contexts. However, the research results have exposed some certain values: Theoretically, the research inevitably contributes a part to the existing knowledge of successful English-speaking teaching through the design and application of computer-based activities. Furthermore, it is expected that the study's findings would be a source of reference for teachers to find better and effective methods for their classroom language teaching in similar contexts and might be a suggestion to further research related to the use of CBA in teaching English in general and English speaking in particular; Practically, the findings of this study would be beneficial for the teachers and learners at the high school where the research was conducted because the teachers might raise their awareness about the effects of using computer-aided learning in teaching English speaking to improve the speaking competence of students. Moreover, the teachers at this high school could find better and effective methods for their classroom language teaching, i.e., the findings would be helpful for teachers who might find difficulties and depression in making a decision about what ways to design and apply CBA used for improving their students' speaking competence. More importantly, using CBA could be employed as an effective and positive method for learners to improve their language skills, especially speaking. 
Although teachers using computers are highly effective in creating English-speaking teaching activities, computer technology cannot successfully replace humans, so they may be challenged by those able to apply technology. However, hopefully, this present study may serve as a helpful reference for teachers to find better and more effective methods for language teaching in their classrooms in similar contexts in different high schools in Ho Chi Minh City.

\section{Acknowledgments}

It can be seen that, when teachers use CBA in their speaking classes, students have many opportunities to participate in the conversation, individual practice, pairs, groups, and presentations. Therefore, it is strongly recommended that teachers and students in Vietnam's high schools should take technology advantages into their teaching and learning. By creating different computer-based activities in the classroom, using sounds and images in lectures, those who use the computer to teach and learn with vivid visualizations would gain improvement in their performance.

\section{References}

Afrizal, M. (2015). A classroom action research: Improving speaking skills through information gap activities. English Education Journal, 6(3), 342-355.

AL-Garni, S. A., \& Almuhammadi, A. H. (2019). The Effect of Using Communicative Language Teaching Activities on EFL Students' Speaking Skills at the University of Jeddah. English Language Teaching, 12(6), 72-86. https://doi.org/10.5539/elt.v12n6p72

Alkash, K. A. M., \& Al-Dersi, Z. E. M. (2017). Advantages of using PowerPoint presentation in EFL classroom \& the status of its use in Sebha University. Tersedia http://eltsjournal. org/upload/2014-05-13.

Arkın, E. İ. (2003). Teachers' attitudes towards computer technology use in vocabulary instruction (Doctoral dissertation, Bilkent University).

Ayres, R. (2002). Learner attitudes towards the use of CALL. Computer-assisted language learning, 15(3), 241-249. https://doi.org/10.1076/call.15.3.241.8189

Bachman, L. F., \& Palmer, A. S. (1996). Language testing in practice. Oxford: Oxford University Press, 371 pages.

Bai, Y. H. (2009). On University Students'Attitudes Towards computer-aided English Learning. Sino-US English Teaching, 6(9), 32-36.

Blin, F. (2004). CALL and the development of learner autonomy: Towards an activitytheoretical perspective. RECALL, the Journal of EUROCALL, 16(2), 377-395. https://doi.org/10.1017/S0958344004000928

Brown, G., \& Yule, G. (1983). Discourse analysis. Cambridge: Cambridge University Press. 
Burns, M. (2010). How to help teachers use technology in the classroom: The 5J approach. eLearn, 2010(9). https://doi.org/10.1145/1858579.1865476

Chairat, P. (2018). The potential benefits of internet-based learning in Thai EFL context. Asian ESP Journal, 14(4), 62.

Chau, K. G. (2021). The Effect of ICT on Learners'Speaking Skills Development. International Journal of TESOL \& Education, 1(1), 22-29. Retrieved from $\underline{\text { http://ijte.org/index.php/journal/article/view/4 }}$

Chirimbu, S., \& Tafazoli, D. (2013). Technology \& media: Applications in language classrooms (TEFL, TESL \& TESOL). Professional Communication and Translation Studies, 6(1-2), 187-194.

Council of Europe (2018). Common European Framework of reference for languages: learning, teaching, assessment companion volume with new descriptors. Strasbourg: Council of Europe.

Fouz-González, J. (2017). Pronunciation instruction through Twitter: the case of commonly mispronounced words. Computer Assisted Language Learning, 30(7), 631-663. https://doi.org/10.1080/09588221.2017.1340309.

Genç, G., \& Aydin, S. (2011). Students' motivation toward computer-based language learning. International Journal of Educational Reform, 20(2), 171-189. https://doi.org/10.1177/105678791102000205

Ginkel, S. V., Gulikers, J., Biemans, H., \& Mulder, M. (2015). Towards a set of design principles for developing oral presentation competence: A synthesis of research in higher education. Educational Research Review, 14, 62-80. https://doi.org/10.1016/j.edurev.2015.02.002

Guillén, G. (2014). Expanding the language classroom: Linguistic gains and learning opportunities through e-tandems and social networks. $\mathrm{PhD}$. dissertation, University of California, Davis.

Haitao, M. (2011, May). Computer-based student-centered classroom in English language teaching. In 2011 International Conference on Business Management and Electronic Information (Vol. 2, pp. 714-717). IEEE. https://doi.org/10.1109/icbmei.2011.5918012

Hornby, A. S., Wehmeier, S., \& Ashby, M. (2000). Oxford Advanced Learner's Dictionary: Oxford University Press. NewYork City, USA.

Hulstijn, J. H., Hollander, M., \& Greidanus, T. (1996). Incidental vocabulary learning by advanced foreign language students: The influence of marginal glosses, dictionary use, and reoccurrence of unknown words. The modern language journal, 80(3), 327-339. https://doi.org/10.1111/j.1540-4781.1996.tb01614.x

Jarvis, H., \& Achilleos, M. (2013). From Computer Assisted Language Learning (CALL) to Mobile Assisted Language Use (MALU). Tesl-EJ, 16(4), n4. 
Jin, L., \& Deifell, E. (2013). Foreign language learners' use and perception of online dictionaries: A survey study. Journal of Online Learning and Teaching, 9(4), 515.

Jones, R. E. (2001). A consciousness-raising approach to the teaching of conversational storytelling skills. ELT Journal: English Language Teaching Journal, 55(2), 155-169.

Kuning, D. S. (2019). Technology In Teaching Speaking Skill. Journal of English Education, Literature and Linguistics, 2(1), 50-59. https://doi.org/10.31540/jeell.v2i1.243

Levy, M. (1997). Computer-Assisted language learning. Context and conceptualization. Oxford: Oxford University Press.

Little, D. (2007). Language learner autonomy: Some fundamental considerations revisited. International Journal of Innovation in Language Learning and Teaching, 1(1), 14-29. https://doi.org/10.2167/illt040.0

Luppescu, S., \& Day, R. R. (1993). Reading, dictionaries, and vocabulary learning. Language learning, 43(2), 263-279. https://doi.org/10.1111/j.1467-1770.1992.tb00717.x

Marco, M. J. L. (2002). Internet Content-Based Activities for English for Specific Purposes. In Forum, 40 (3), 20-25. Retrieved: http://exchanges. state. gov/forum/.

Medvedev, G. (2016). Google translate in teaching English. Journal of Teaching English for Specific and Academic Purposes, 4(1), 181-193.

Morreale, S. P., \& Pearson, J. C. (2008). Why communication education is important: The centrality of the discipline in the 21 st century. Communication Education, 57(2), 224240. https://doi.org/10.1080/03634520701861713

Muir-Herzig, R. G. (2004). Technology and its impact in the classroom. Computers \& Education, 42(2), 111-131. https://doi.org/10.1016/S0360-1315(03)00067-8

Muijs, D. (2004). Doing quantitative research in education with SPSS. Sage.

Murphy, K. (1991). Patronage and an oral tradition: Influences on attributions of distance learners in a traditional society (A qualitative study). Distance Education, 12(1), 27-53. https://doi.org/10.1080/0158791910120104

Neumeyer, L., Franco, H., Digalakis, V., \& Weintraub, M. (2000). Automatic scoring of pronunciation quality. Speech communication, 30(2-3), 83-93. https://doi.org/10.1016/S0167-6393(99)00046-1

Nguyen Thi Nhu Ngoc (2017). Computer-based activities for translation courses at Tertiary Level: A Case Study in Vietnam. International Journal of Language and Linguistics, 4 (3), 42-48.

Nguyen, B. V., \& Ngo, T. C. T. (2021). Using the Internet for self-study to improve translation for English-majored seniors at Van Lang University. International Journal of TESOL \& Education, 1(2), pp. 110-147. http://eoi.citefactor.org/10.11250/ijte.01.02.007 
Nunan, D. (1999). Second language teaching \& learning. Heinle \& Heinle Publishers: Boston, Massachusetts, USA.

O’Dowd, R. (Ed.). (2007). Online intercultural exchange: An introduction for foreign language teachers. Multilingual Matters. https://doi.org/10.21832/9781847690104

Oradee, T. (2012). Developing speaking skills using three communicative activities (discussion, problem-solving, and role-playing). International Journal of Social Science and Humanity, 2(6), 533.

Parveen, B. W. (2016). Use of technology in improving speaking skills. Journal of English language and literature (JOELL), 3(2).

Pearcey, P. A., \& Elliott, B. E. (2004). Student impressions of clinical nursing. Nurse education today, 24(5), 382-387. https://doi.org/10.1016/j.nedt.2004.03.007

Pham Ngoc Truong Linh (2017). Effects of Communication-Based Translation Activities on EFL High School Students' Vocabulary Achievement. International Journal of Linguistics, 5(2), 26-39. https://doi.org/10.15640/ijlc.v5n2a3

Prince, J. (2017). English Language Learners in a Digital Classroom. CATESOL Journal, 29(1), 51-73.

Quoc, T. X., Thanh, V. Q., Dang, T. D. M., Mai, N. D. N., \& Nguyen, P. N. K. (2021). Teachers' perspectives and Practices in Teaching English Pronunciation at Menglish Center. International Journal of TESOL \& Education, 1(2), 158-175. http://eoi.citefactor.org/10.11250/ijte.01.02.009

Rahimi, M. (2011). The impact of computer-based activities on Iranian high-school students' attitudes towards computer-assisted language learning. Procedia computer science, 3, 183-190. https://doi.org/10.1016/j.procs.2010.12.031

Savignon, S. J. (1991). Communicative Language Teaching: State of the Art. TESOL Quarterly, 25(2), 261-278. https://doi.org/10.2307/3587463

Schwienhorst, K. (2008). Learner autonomy and CALL environments. New York: Routledge.

Seidlhofer, Barbara. (2011). Understanding English as a Lingua Franca. Oxford: Oxford University Press.

Staff, M. W. (2004). Merriam-Webster's collegiate dictionary (Vol. 2). Merriam-Webster.

Stepp-Greany, J. (2002). Student perceptions on language learning in a technological environment: Implications for the new millennium. Language learning \& technology, $6(1), 165-180$.

Sundkvist, P., \& Nguyen, X. N. C. M. (2020). English in Vietnam. The Handbook of Asian Englishes, 683-703. Wiley Blackwell Publisher.

https://doi.org/10.1002/9781118791882.ch30 
Tran, O. T. T. (2021). The Efficiency of E-teaching Activities in Teaching Speaking Skills for English Major Students. AsiaCALL Online Journal, 12(4), 1-8. Retrieved from https://asiacall.info/acoj/index.php/journal/article/view/51/33

Uchihara, T., \& Saito, K. (2016). Exploring the relationship between productive vocabulary knowledge and second language oral ability. The language learning Journal, 47(1), 6475. https://doi.org/10.1080/09571736.2016.1191527

Uzunboylu, H. (2004). The effectiveness of web assisted English language instruction on the achievement and attitude of the students (pp. 727-733). Association for the Advancement of Computing in Education (AACE).

Warschauer, M., \& Healey, D. (1998). Computers and language learning: An overview. Language Teaching, 31(2), 57-71.

Warschauer, M., \& Kern, R. (Eds.). (2000). Network-based language teaching: Concepts and practice. Cambridge University Press.

\section{Biodata}

Nguyen Thi My Nhu is currently an English teacher at Binh Hung Hoa High School, Ho Chi Minh City, Vietnam. She is also studying for a master's degree in English language at Hutech University. She has been teaching since 2009. She has always been passionate about research on English language, translation and application of information technology in teaching. 